\title{
Civil Society over Political Power
}

\section{Javad Bahmani* and Massoud Jafarinejad ${ }^{2}$}

${ }^{1}$ Department of Political Sociology, Islamic Azad University of Shahreza, Iran

${ }^{2}$ Department of Political Science and International Relations Faculty of Humanities, Islamic Azad University of Shahreza, Iran

\begin{abstract}
The human and his right-oriented demands were analyzed and theorized since the basis of idea in modern society was established by thinkers such as Hobbes, Locke, Rousseau, Bentham, and Stuart Mill during the $17^{\text {th }}$ and $18^{\text {th }}$ centuries. The role of civil society in inhibition of political power is the neglected point in this set of thought. How the civil society should react to momentary and weapons policies as an observer? The political powers have now become powerful based on the investors' interactions and different lobbies after centuries. Playing with public thoughts of power is carried out beyond the movies, and it results in domination over the news sources and agencies, and promoting a up-down order. I am seeking to share some of my thought here.
\end{abstract}

Keywords: Civil society; Power; Interests

\section{Introduction}

Past centuries have been faced with different social movements and revolutions since the most primitive ones in France, England and the United States, etc. Gradually, the scholars have found that we are in the end of history and the best option is found in governing the countries. However, does the human intellectual development has reached the stagnation point and there is no need to look again to function of this state structure. Is the liberalism or democracy actually the end point of human mission in intellectual development? As a large number of countries have had this strategy and government and pass the second and third movements since 1975, why I should argue that the human is still immature and undeveloped intellectually? I hope my reasons attract the attention and challenge this view.

\section{Evolution of Human Thought}

Considering the era of fire discovery and gathering in caves as the origin of learning for more safety, this movement had focused on protecting the body and assets from other people and their robbery and attack at the same time with states with absolute tyranny in Europe. In this regard, the thinkers like Aquinas fought against the church to establish new intellectual basis. His foundation based on humanism finally was imposed on society and became common as immature baby in countries and it became possible by the help of absolute authoritarian states. In accordance with laws and agreement with big landowners, they did not intervene in their private properties, and this cycle facilitated moving towards the industrial capitalism and ultimately led to the constitutional powers and economic freedoms and then the political freedom. This is much easier in states with the abovementioned conditions, but the authoritarian state did not have any condition for itself, and thus the private investment failed and became unsafe in our country.

\section{Promise of Political and Economic Freedom}

After this process and inspired by the great thinkers' thoughts, drawing the state framework based on humanism, the Aristotle look gradually overcame the Plato's, and led to change in thoughts of different groups of people who deprived of basic rights to vote and also the primary rights. None of the people did the slavery and women demanded their rights. Therefore, the international human rights convention was drawn. At this stage, the main question arises: Does the human reach all its goals and there is no need to look again to the past if all conventions of human rights are implemented around the world.

\section{Civil Society}

The modern human, who has passes the process before the modernity, knows the specific rights for himself now such as participation in Syndicates, classes, various party, art, etc groups. In other words, he has become free and when he gets out of house, he does anything without harming the other people's freedom. The right to vote and a life with well-being, health, treatment, recreation, sports and whatever the human thinks as the welfare should be prepared for him because this is the macro-strategy of humanist countries.

\section{Political Populism}

In countries, where are known as those with democracy, the government is elected based on promotion process. Who gives direction to this massive propaganda? Not all of it, but a major part is done by financiers and lobbyists who have different demands from government after the election and numerous ones may not be in line with public interest. However, the news agencies and online video media and tens of other promotions advertise for any candidate by receiving money. Does this situation create a dominating space on public opinion and end in tyranny of majority over the minority? This is called the worst form of tyranny according to a group of scholars.

\section{Political Power}

Now, in freedom of civil society in countries which are established based on public elected institution in terms of democracy of governing political power, what is the tool in this regard? Should we afraid of a very large space for political propaganda, intelligence agencies, military, very broad bureaucratic structure and monetary assets which can be increased to thousand times by capitalists' collaboration? While the civil society and its productive leverage are deprived of all mentioned cases, and it can only offer the tension and insecurity against that

*Corresponding author: Bahmani J, Department of Political Sociology, Islamic Azad University of Shahreza, Iran, Tel: 44865179-82; E-mail: javadbahmanistu@gmail.com

Received December 28, 2016; Accepted February 06, 2017; Published February 14, 2017

Citation: Bahmani J, Jafarinejad M (2017) Civil Society over Political Power. Inte Prop Rights. 5: 176. doi: 10.4172/2375-4516.1000176

Copyright: (c) 2017 Bahmani J, et al. This is an open-access article distributed under the terms of the Creative Commons Attribution License, which permits unrestricted use, distribution, and reproduction in any medium, provided the original author and source are credited. 
unlimited power at the time when the government is taking the wrong steps and the negotiation is useless. I ask again, is it not scary?

\section{What I think is as follows}

According to a very brief assessment of scope in this article for leading the reader to think, I offer the solution for this huge challenge according to my opinion.

I do not want to ignore the great scholars of politics and political philosophy, but I do not doubt that they have neglected the great point. If the governments should move as the entities under the vision and will of society, how we can guarantee the necessary control and inhibition in use of governmental power. As I said, the political structures such as the parties plan for votes only for fulfilling their own needs. Here, my final card should be seen and the civil society must participate in power structure and cover this huge gap as the most important decisionmaking basis.

\section{Presence of Civil Society in Power Structure}

The civil society consists of the whole population with an almost regular organization and this order should be doubled. At the next stage, the necessary separation based on the jobs and expertise should be done in more regular way in civil society. Each of civil societies should be registered independently. The candidates, with concerns in line with concerns of civil society groups, should be elected across the country in federal way. This assembly as the highest decision-making sector is controlled by state in use of weapons inside or outside country. The use of all state facilities is completely monitored by this assembly. As soon as elected people by various civil society groups deviate from their duties, they will be fired at the moment and they will be replaced in order to take care of civil society interests.

\section{Conclusion}

The society members or the civil society are those who sacrifice their life and property for governors' decision-making. Their decisions should be confirmed by civil society, and thus the minorities support their parliament members in civil society. Nobody is permitted to use weapon, but for ask of civil society and consideration of benefits. The aborted evolution of human thought is restarted in this case, and the thinkers establish a principled structure which should be approved by civil society [1-4].

\section{References}

1. Sariolghalam M (2012) Rationality and Iran's development. Publishers farzaniran, print year six print.

2. Ashori D (2006) We and modernity.

3. Chavam A (2009) Political development challenges.

4. Milani A (2005) Battle of modernization and modernity in Iran. 